\title{
Virginia Woolf's History of Sexual Victimization: A Case Study in Light of Current Research
}

\author{
Lucia C. A. Williams \\ Department of Psychology, The Laboratory of Violence Analysis \& Prevention (LAPREV), Federal University of \\ São Carlos, São Carlos, Brazil \\ Email: williams@ufscar.br
}

Received 2 May 2014; revised 29 May 2014; accepted 24 June 2014

Copyright @ 2014 by author and Scientific Research Publishing Inc. This work is licensed under the Creative Commons Attribution International License (CC BY). http://creativecommons.org/licenses/by/4.0/

(c) (i) Open Access

\begin{abstract}
Virginia Woolf's history of sexual victimization is presented in a case study format, and reviewed in light of the present literature on the impact of child sexual abuse (CSA) to human development. The methodology to compose the case study involved reviewing the works of Woolf's main biographers, the author's memoirs, and the groundbreaking work of Louise DeSalvo, presenting data from Woolf's diaries and letters, in which sexual abuse is disclosed. Woolf was sexually abused by her two older half-brothers. The abuse was extremely traumatic, and lasted several years. The various mental health symptoms that Woolf experienced are consistent with the literature of CSA. Woolf also presented some adequate coping skills by disclosing the CSA publicly, keeping records of her depressive episodes, and seeking help. Like many incest survivors, Woolf's sexual abuse was minimized and questioned by biographers. In addition to Woolf's enormous literary legacy, her knowledge of psychology was impressive. She was a feminist, as well as a visionary in exploring the effects of CSA before other incest survivors. Understanding her life influences is advantageous, not only to literary scholars but to most readers, and mainly clinicians and researchers are interested in the dynamics of sexual abuse.
\end{abstract}

\section{Keywords}

Child Sexual Abuse, Virginia Woolf's Sexual Victimization, Impact of Sexual Victimization, Dynamics of Child Sexual Abuse

\section{Introduction}

The goal of the present paper is to review Virginia Woolf's history of victimization, in light of the present litera- 
ture about the short and long term impact of child sexual abuse (CSA). Shedding light on Woolf's sexual abuse victimization may illustrate to clinicians, students and other professionals the present status of knowledge regarding child sexual abuse as a life stressor, an area in which psychological science has had a significant contribution in the last three decades.

Virginia Woolf remains one of the most impressive English authors to date, and understanding her life influences is also advantageous, not only to literary scholars. Readers in general would benefit from this analysis, as Woolf`s sexual abuse was minimized and questioned by biographers who were not specialists in psychology or sexual abuse.

The methodology to develop this case study involved reviewing the works of Woolf's main biographers and the author's memoirs. Particularly helpful was the groundbreaking work of DeSalvo (1989), presenting data from Woolf's diaries, letters, and sketches in which Woolf discloses sexual abuse. Surprisingly, DeSalvo's book on Woolf's CSA history has not achieved the attention it deserves. Constructing Woolf's case study in the present paper involved reading most of the original materials quoted by DeSalvo, as well as examining other pertinent publications available on Woolf, particularly material published after DeSalvo's 1989 book.

In spite of the book's depth, DeSalvo writes from a comparative literature perspective, and not from a standpoint of psychology, mental health or as a specialist in child maltreatment. Although DeSalvo's book subtitle is "The impact of childhood sexual abuse on her life and work", the author has two intentions with her text: to use Woolf's works to describe the world of the child and adolescent as the writer understood it, and to "form a portrait of how Virginia Woolf perceived and described herself and her experiences as a child and adolescent by using both works that she wrote...” (DeSalvo, 1989: p. xiii).

When describing the influences which helped her achieve her objectives, DeSalvo identifies: "insights from the disciplines of feminist inquiry, the history of the family, Victorian studies, and the changes in psychoanalytic theory that stress personal history, rather than internal drives as causative factors in neurosis” (1989: xvi). As this researcher believes that other influences may also help with this discussion, the goal of the present paper is to organize and expand DeSalvo's information from the perspective of psychological science, presenting Woolf's CSA history.

\section{Virginia Woolf's Family Background}

A genogram of Woolf's family in Figure 1 below helps us visualize the biographic information detailed by DeSalvo (1989), and Woolf's main biographers (Bell, 1972; Lee, 1999; Marder, 2000). Woolf was born, in 1882, to Leslie Stephen and Julia Jackson. Woolf's parents had been previously married, and both had children from previous relationships: Leslie had one daughter (Laura) who was 12 when Woolf was born, and Julia had George, Stella and Gerald who were 14, 13 and 12 when the famed writer was born. A total of four children were born to Leslie and Julia's relationship, in this order: Thoby, Vanessa, Virginia and Adrian.

Woolf suffered sexual abuse by her half brothers: George and Gerald. According to her own testimony, the abuse began "when she was about six years old" (DeSalvo, 1989: p. xii).

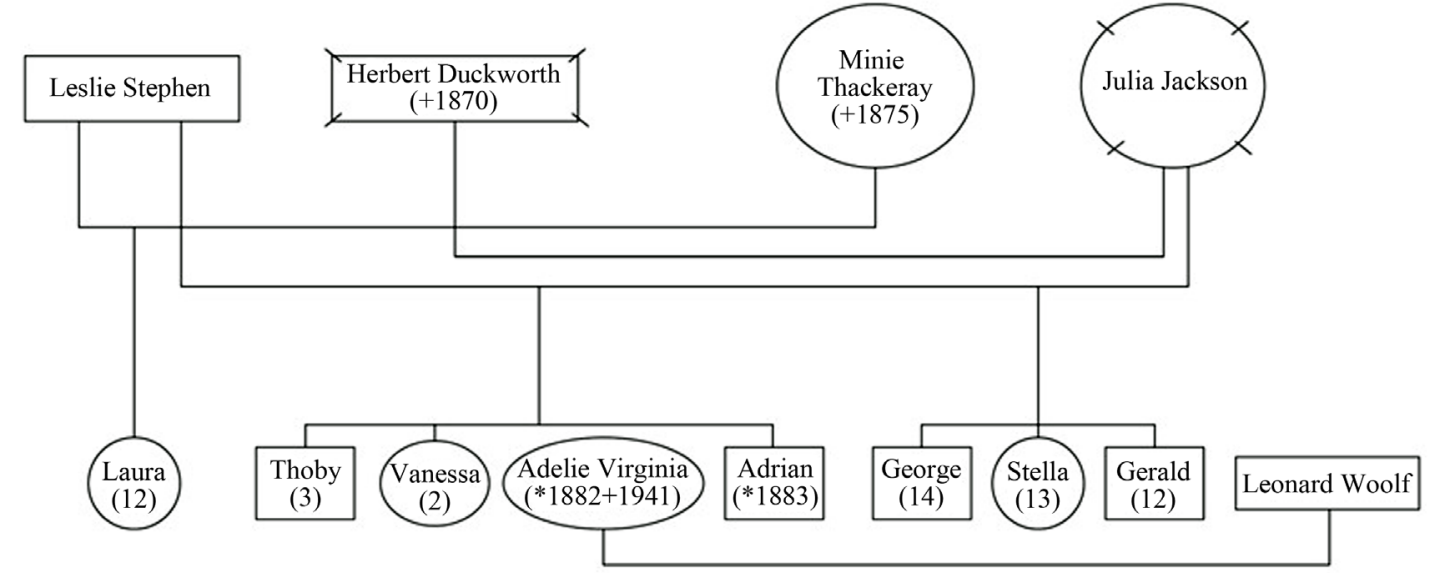

Figure 1. Virginia Woolf's family genogram. 


\section{Woolf's History of Sexual Abuse}

Virginia Woolf was “an incest survivor” (DeSalvo, 1990: p. 1). She was sexually abused by her two older halfbrothers George and Gerald Duckworth, according to her own testimony. DeSalvo (1989) characterizes the abuse reported by Woolf as being "extremely traumatic", and identifies variables which may be categorized in this case study as the following risk factors: 1) "she was abused when young” (p. 8); 2) the abuse had long duration (it started when Woolf was about six or seven, and only stopped when she was 24); 3) "it probably involved many incidents" (p. 8); 4) the abuse was perpetrated by close trusted members of the family, that is, it was incestuous in nature; 5) there was more than one perpetrator; and 6) "another member of the family was also abused” (p. 8), referring to Woolf's sister Vanessa.

To these factors, the present author adds others that DeSalvo gives evidence to: 7) the topography of the sexual acts apparently involved penetration; 8) her parents, for whatever reasons, did not seem to make efforts to protect her from the abuse; and, finally, 9) she did not receive appropriate treatment for her CSA. All the above variables are described by the literature as moderating risk for symptomatology of child sexual abuse (Deblinger \& Heflin, 1996; Follette, 1994; Kaplow et al., 2008; Kendall-Tackett, Williams, \& Finkelhor, 1993; Meichenbaum, 1994; O’Donohue, Fanetti, \& Elliot, 1998).

In contrast, Woolf took some important initiatives associated with positive coping skills. She did not keep the abuse secret-according to DeSalvo (1989) she disclosed it “often in graphic detail” (p. 121) to her sister Vanessa; to her brother-in-law Clive Bell (Vanessa’s husband); to her own husband Leonard Woolf; to her lovers and friends; and, most importantly, she made it public by disclosing aloud at the Memoir Club. The latter consisted of a group of close intellectual friends (the famous Old Bloomsbury or simply Bloomsbury), formed in 1920, who gathered at intervals to dine, and to read intimate memoirs with "absolute frankness” (Schulkind, 1985: p. 161).

DeSalvo (1989) quotes from Woolf's autobiography Moments of Being, explaining that Vanessa even made an effort to disclose Woolf's sexual abuse by George to their family doctor (Dr. Savage), who confronted him. George, on the other hand, justified his behavior to the physician as efforts to "comfort" his sister "for the fatal illness of my father” (DeSalvo, 1989: p. 303). According to DeSalvo, Woolf started to write about her sexual problems in a short story when she was 10 , and continued to do so throughout her life in letters, in her diary, and in her autobiography.

Writing and describing traumatic episodes is a research-based technique of gradual exposure associated with recovery from abuse (Deblinger \& Heflin, 1996; Foa, Molnar, \& Cashman, 1995; Follette, Ruzek, \& Abueg, 1998). Interestingly, DeSalvo has summarized psychology’s research contribution investigating the health benefits of writing, in another book she authored-Writing as a way of healing (DeSalvo, 1999), based on the accumulated experience she has had for decades teaching her Hunter College students to write stories that would transform their lives.

DeSalvo (1989) reproduces Woolf's graphic disclosures of her CSA incidents from Moments of Being. Apparently the first abuse episode was initiated by Gerald Duckworth, when she was six or seven (her half-brother would have been 18 or 19$)$ :

"As I sat there he began to explore my body. I can remember the feel of his hand going under my clothes; going firmly and steadily lower and lower, I remember how I hoped that he would stop; how I stiffened and wriggled as his hand approached my private parts. But it did not stop. His hand explored my private parts too” (p. 104).

In contrast, her older brother's abuse (George Duckworth) began after their mother's death: Woolf was 13, and George around 28. DeSalvo (1989) reproduces Woolf's extraordinary disclosure to the Memoir Club, entitled “22 High Park Gate”:

"She tells how, in a 'confused whirlpool of sensation' she undressed in her room in her adolescence, how she stretched out on her bed to fall asleep, and how George invaded her room: 'creaking stealthily, the door opened; treading gingerly, someone entered'. 'Who?' I cried. 'Don't be frightened', George whispered. 'And don't turn on the light, oh beloved'. Beloved—and he flung himself on my bed, and took me in his arms” ( p. 121).

This researcher found it puzzling that Woolf and her biographers provide little information on the writer's relationship with Gerald throughout her life. Woolf is loquacious about George and dismissive of her first sexual 
offender. In the absence of data, we can only speculate that the first CSA incident was extremely traumatic (leading perhaps to Post-traumatic Stress Disorder), as “denial”, and "emotional suppression” are coping methods frequently associated with poorer adult psychological adjustment (Leitenberg, Greenwald, \& Cado, 1992).

\subsection{Short and Long-Term Consequences of Woolf's Abuse}

From the data presented by DeSalvo based on Woolf's information compiled from her autobiography A Sketch of the Past, we may categorize the following possible symptoms presented by Woolf as a child:

1) Depression and isolation... "a feeling of hopeless sadness... I slunk off alone, feeling horribly depressed (DeSalvo, 1989: p. 106), and "I feel so alone, so alone, all alone..." (p. 107);

2) Extreme passivity (when describing a physical fight she had with her brother Thoby, on the lawn) - "I dropped my hand instantly, and stood there, and let him beat me” ... "I became aware of something terrible; and of my own powerlessness" (p. 106);

3) Guilt and embarrassment- "I still shiver with shame at the memory of my half brother, standing me on a ledge, aged about 6 , and so exploring my private parts. Why should I have felt shame then?” (p. 119), "it is wrong to allow parts of the body to be touched (p. 108);

4) Body shame-DeSalvo explains that Woolf referred as a "looking-glass shame" or "looking-glass complex" her difficulty looking in the mirror without diverting her eyes, as she was "ashamed or afraid of my own body" (104). In an attempt to explain this, Woolf "toys with the idea that it was inherited" (DeSalvo, 1989: p. 104), but DeSalvo correctly hypothesizes that the mirror was a stimulus paired with Gerald Duckworth's sexual abuse previously described-"I strongly suspect that what intensified the horror of the experience was the fact that Woolf was able to see herself in the mirror: she was watching herself being assaulted" (p. 105);

5) Additionally, based on the information given by DeSalvo we may also suggest: dissociation symptomswith regards to an excerpt she quotes from a letter in which Woolf mentions a "disembodied trance-like intense rapture that used to seize me as a girl" (p. 103); as well as Woolf's comments in another letter when crossing a path: "everything suddenly became unreal; I was suspended; I could not step across the puddle" (DeSalvo, 1989: p. 105), among other examples.

All symptoms listed above have been found by clinicians and trauma researchers as possible side effects of traumatic episodes, in particular sexual trauma. Children with recurrent abuse episodes will frequently experience dysphoric emotions and an unwillingness to experience unpleasant events, such as thoughts and feelings associated with the abuse as in the "looking-glass shame" (Briere, 1992; Follette, 1994; Kendall-Tackett, Williams, \& Finkelhor, 1993; Meichenbaum, 1994). Specifically in terms of dissociation, its association with childhood sexual trauma in children and adults has been widely studied (Wagner \& Linehan, 1998).

As an adolescent and adult, we may categorize the symptoms presented by Woolf and referred to by DeSalvo, in the following ways:

1) Eating disturbances-DeSalvo argues that the reason Woolf had difficulty eating was related to the fact that Gerald's first episode of abuse occurred while she was sitting on a ledge which held plates near the dining room; DeSalvo's descriptions of Woolf's refusal to eat are similar to partial anorexia symptoms;

2) Sexual difficulties in heterosexual relations-although Woolf did not consider herself a homosexual, she did not have sex with her husband, and "chose lesbian love, with Violet Dickison and with Vita Sackville-West, as a positive, adaptive response to her abuse” (DeSalvo, 1989: p. 119);

3) Sexualized interpersonal relations-Woolf had sex with her sister Vanessa, and her brother-in-law, Clive Bell, Vanessa's husband. DeSalvo appropriately remarks that confusing sex with affection is often observed in incest survivors;

4) Sleep disturbances-DeSalvo quotes Love (1977) on the fact that Woolf "was terrified of going to sleep" (p. 12). Marder (2000), who writes about Woolf's last ten years of life, mentions that Woolf would stay up until 3 a.m. fighting her suicidal thoughts;

5) Depression-Woolf's feelings of hopelessness and lack of control continued from childhood, and pursued the author throughout life. DeSalvo informs that Woolf tried to study her own depression by taking careful notes in her diary, and examining mood patterns;

6) Suicide ideation and suicide attempts—Woolf often had what she called a "suicide dream"- "a recurrent dream that overwhelmed her with terror: it was a dream of being alone, on the inside of a drainpipe, and at the end of the drainpipe was madness” (DeSalvo, 1989: p. 105); 
7) Nervousness, irritability, humor explosions and "breakdowns"-DeSalvo quotes Quentin Bell (1972), Woolf's official biographer and nephew (Vanessa's son), describing her first 'breakdown”, and stating that he does not know enough about her mental illness "to say whether or not this adolescent trauma (the sexual abuse by George) was in any way connected” (DeSalvo, 1989: p. 3). Biographer Frank Kermode informs that Woolf's first breakdown occurred when Julia Stephen died, in 1895, "possibly related in some way to the sexual molestation of which her half-brother is accused” (Kermode, 2000: p. viii). DeSalvo (1989) quotes Stephen Trombley's, 1981, "All that Summer she was mad", arguing that Woolf's biographers often portray the author as insane. DeSalvo, however, acknowledges Trombley's insight when stating that "Virginia's anxious, 'mad' behavior was a response to her incestuous experiences" (DeSalvo, 1989: p. 5). The symptoms apparently present in such breakdowns involved: "the inability to read or concentrate; depression; feelings of dread...; confusion; hallucinations; failure of appetite; 'a dry and unpleasant feeling in the throat...' and loss of power within the limbs” (DeSalvo, 1989: p. 5). The following paragraphs will present evidence that the above symptoms identified by DeSalvo find solid echo in psychological literature.

Since the 1990s, investigators have examined whether child sexual abuse might play a role as a risk factor for eating disorders (ED), particularly in females (Thompson \& Wonderlich, 2004). It appears that CSA victimization may promote dysregulated behavioral control, such as impulsivity and compulsivity as a coping strategy for some survivors (Dworkin, Javdani, Verona, \& Campbell, 2014). To this effect, research data has initially shown an association, but less robust (Cohen, 1995) than clinicians have observed in their practice. A longitudinal cohort study of 1936 female adolescents from Australian schools, attempting to examine the relationship between CSA and later onset of bulimia and anorexia symptoms, found significantly higher incidence of bulimic behaviors which increased with number of episodes of CSA; however little evidence of an association between CSA and partial anorexia was observed (Sanci et al., 2008). A meta-analysis examining results from 53 studies analyzing the association between CSA and ED (Smolak \& Murren, 2002), found a small significant relationship between these two variables.

DeSalvo's argument about Woolf's pairing of CSA with an environment strongly related to eating makes sense from a cognitive-behavioral perspective. As in the "looking-glass complex" situation, classical conditioning has provided the central idea that stimuli associated with traumatic events can, through learning, come to elicit responses similar to those shown during exposure to trauma-fear, for example (see Follette, Ruzek, \& Abueg, 1998). Thus, a stimulus which was originally neutral or positive (dining-room or food) may become aversive, and trauma related thoughts and images may then occur in situations in which no further traumatic exposure appears. In the behavioral model, classical conditioning explains basic fear acquisition, and operant conditioning explains the avoidance behaviors. In such model, the person is unwilling to experience the unpleasant internal events (thoughts and feelings) associated with the abuse (Follette, 1994). Lastly, cognitive researchers have demonstrated that negative beliefs, such as loss of confidence in the "fairness and benevolence of the world" (DeSalvo, 1989: p. 6) helps maintain these symptoms with anxiety disorders (Follette, Ruzek, \& Abueg, 1998).

In terms of Woolf's sexuality, CSA is considered an important moderator of the association between sexual functioning and distress in women (Stephenson, Hughan, \& Meston, 2012). Authors have also suggested that CSA survivors may also face important issues related to sexual health (Lemieux \& Byers, 2008). CSA survivors' viewing sex as necessary for affection is a common claim within the literature (Simon \& Feiring, 2008), and survivors of more severe CSA have engaged in more high-risk sexual behaviors, such as a greater number of sexual partners (Fergusson, McLeod, \& Horwood, 2013; Lacelle et al., 2012).

Sleep disturbances have been associated with CSA since the 1980s (Browne \& Finkelhor, 1986), as well as with cumulative trauma and posttraumatic stress (Finkelhor, 1990; Follette et al., 1996). In Woolf's case, much of the CSA perpetrated by George described by the author, occurred in her bedroom, as she attempted to sleep, which would leave her in a state of continuous vigilance. In addition, one of her biographers (Marder, 2000) associates Woolf's insomnia with suicide ideation.

Studies have documented that a CSA history is significantly correlated with major depression as an adult (Fergusson, McLeod, \& Horwood, 2013; Follette, 1994; Meichenbaum, 1994), and there is presently considerable evidence in the literature for a strong and direct risk between CSA and suicide (Cashmore \& Shackel, 2013; Chelf \& Ellis, 2002; Evans, Hawton, \& Rodham, 2005). In an Australian study with 2.485 adolescents (Martin et al., 2004), girls who reported high levels of discomfort from the CSA experienced had three times more chances of having suicide ideation when compared to non-victims; in addition $29 \%$ of these girls had attempted suicide.

After reviewing the literature on CSA and suicide, Maniglio (2011) defends that certain biological and psy- 
chosocial variables, such as serotonin hypoactivity and genes, family difficulties including maltreatment, and some personality traits and psychiatric disorders, may either act independently or interact with CSA to promote suicide in abuse victims-in other words, CSA may present itself as an additional risk for suicide, either as a "distal" and indirect cause or as a "proximal" and direct cause. DeSalvo (1989) reports that the threat of a Nazi invasion led Woolf, and her Jewish husband, to make suicidal plans. She quotes Woolf's diary entry from June 2, 1940, mentioning that she and Leonard would be "in concentration camps or taking sleeping draughts" (DeSalvo, 1998, p. 129). Life was certainly very threatening for the couple that particular year. Marder (2000) informs that on August 16, 1940, Virginia and Leonard were in their garden when a German airplane dropped a bomb nearby. Air raids became customary, and Woolf's London house was eventually destroyed in September of the same year (Marder, 2000).

Woolf killed herself on March 28th of the following year by drowning. She placed a large stone in her coat's pocket before entering the river Ouse, leaving Leonard suicide notes, in which she thanks him for his patience and for making her happy, but admits that she is going mad again, as she begins to hear voices, and cannot read nor write (Marder, 2000). Marder (2000) describes Woolf as "manic-depressive” (46), and reports that Woolf went comatose after taking an excessive dose of Veronal shortly after her wedding, in 1912. His description of Woolf's mood instability, ranging from catatonic to physically agitated, may well characterize bipolar disorder. Chilean psychiatrist Figueiroa (2005) analyzes retrospectively Woolf's depressive episodes, as well as suicide attempts, concluding that she meets criteria for bipolar disorder. Biographer Lee (1999) also acknowledges that Woolf has been diagnosed as bipolar; informing that she has had five suicide attempts in her life.

Regardless of the psychiatric diagnosis, what is at stake here is the possibility of Woolf's severe sexual abuse history functioning as a stressor which, combined with a biological vulnerability, triggers a serious mental health problem that perhaps would not have manifested itself without the stressor (Padovani \& Williams, 2010). Indeed, a meta-analysis of seven meta-analytical publications on CSA found it to be a non-specific risk-factor in the development of various types of psychopathology in adulthood (Hilberg, Hamilton-Giachritsis, \& Dixon, 2011), with varying degrees of severity. Another study, which provided a systematic review of several literature reviews on the effects of CSA (Maniglio, 2009) involving more than 270,000 participants from over 500 studies, agrees that there is evidence that survivors of CSA are significantly at risk of a wide range of medical, psychological, behavioral, and sexual disorders. More recently, the same author concludes after a systematic review of 18 studies involving 2996 adults and youths that CSA is associated either directly or indirectly with clinical phenomena that represent a more severe form of bipolar disorder (Maniglio, 2013).

Additionally, a large study conducted in Australia examining forensic medical records of 2759 sexually abused children to study future adult linkage with a public psychiatric database (compared with a matched random control group with same age and gender), found a rate of psychiatric contact 3.65 higher $(23.3 \%$ versus 7.7\%) in comparison to controls (Cutajar et al., 2010). According to the authors, CSA increased risk for psychosis, affective disorder, and anxiety, among other illnesses. And finally, in a classical study with a sample of 1411 female adult twins, 3 levels of CSA were assessed by self-report and co-twin report (Kendler at al., 2000). Selfreported CSA was positively associated with all disorders, leading the authors to conclude that CSA is causally related to an increase risk for psychiatric and substance abuse disorders. Controlling for family background factors and parental psychopathology produced small to modest reduction in rates-in twin pairs discordant for CSA, the sexually abused twin was at consistently higher risk for psychiatric disorders.

The literature has also made recent efforts to identify biobehavioral pathways in the development with psychopathology associated with CSA (Shenk et al., 2010). Based on prospective data from 52 females with a CSA history and their non-abused comparison group $(n=77)$, these authors found that a prior CSA history predicted an asymmetrical physiological response to stress in late adolescence, which in turn predicted higher levels of depression and antisocial behaviors in young adulthood. Shenk et al. (2010) affirm that while there is still a need for future research with improved methodology on this asymmetry of autonomic nervous system and hypothalamic-pituitary-adrenal axis; it seems that CSA may sensitize females to respond to moderate daily stressors in a manner that places them at higher risk for depression and antisocial behaviors. Finally, Liu (2010) conducted a literature review of the interplay of genetic influences on the development of bipolar disorder (in particular the role of brain-derived neurotrophic factor or BDNF) and early CSA, concluding that present research, although still modest, implicates both CSA and BDNF in the etiology of bipolar disorder.

Child sexual abuse is undoubtedly a strong predictor of adverse physical and mental health outcomes (Koenig et al., 2004). Women with a history of CSA have a substantially increased risk for developing a wide range of 
psychopathology. Most of this association is due to more severe forms of CSA and cannot be explained exclusively by background familial factors. Although other biases cannot be ruled out, the results are consistent with the hypothesis that CSA is causally related to an increased risk for psychiatric disorders, as defended by Kendler et al. (2000).

In reading Woolf's ironic essay Am I a Snob? (part of her autobiography), the present author came across another difficulty Woolf had, not described by DeSalvo (1989), but which could be given the same interpretation as the mirror "complex". In her "dress complex" (Woolf, 1985a: p. 210), or as Lee (1999) describes the "clothes complex" (p. 149, Woolf (1985a) reports that she hates buying clothes, particularly suspenders:

"It is partly, I think, that in order to buy suspenders you must visit the most private room in the heart of a shop; you must stand in your own chamise... I am very shy under the eyes of my own sex when in chamise" (p. 211).

According to the editor (Schulkind, 1985), Woolf had originally written in the above extract "you must undress" instead of "you must stand in your own chamise". This difficulty in buying clothes, perhaps because she was anxious about undressing in a public place, and thus possibly related to her body shame, interfered in her daily life activities. She "hated" buying clothes, but she also hated "being badly dressed" (Woolf, 1985a: p. 185). She reports having missed several social engagements-one of them involved not having the opportunity to meet poet Paul Valery-because she did not have proper clothes.

Lee (1999) downplays the influence of sexual abuse in Woolf's life, stating that there is something inconclusive about her CSA memories. This biographer raises the possibility that Woolf's satire of George may not be due to CSA but to his bourgeois Victorian behavior; she admits that Woolf considered the George to have damaged her life, but Lee claims that Woolf "used George as an explanation for her terrifyingly volatile and vulnerable mental states” (p. 156). Finally Lee is also far from understanding the ambivalent dynamics of CSA when Woolf reacts to George's death with tenderness. In addition, Lee (1999) criticizes DeSalvo (1989) for constantly over-interpreting and manipulating the evidence on CSA.

Notwithstanding Woolf's description of the CSA she experienced—like many if not most survivors-her episodes of maltreatment were misunderstood, minimized or simply not believed by scholars who studied her. Most biographers such as Lee, although coming from a literary background do not have the modest attitude that Woolf's nephew had when admitting that CSA and mental health knowledge were out of his domain (Bell, 1972).

DeSalvo (1989) quotes from Love's Sources of Madness and Art (1977), in which Love states that it cannot be determined that the alleged offenses actually took place, as it is possible that "they were imaginative elaborations of some innocent action", as well a consequence of the author's tendency to "extend and embroider actual events" (DeSalvo, 1998: p. 3). DeSalvo also quotes Phyllis Rose (Woman of Letters: A life of Virginia Woolf, 1978), who claims that Woolf made up her incestuous experience, as Rose sees discrepancies in the author's description of CSA by George Duckworth. In regards to this point, DeSalvo appropriately argues that: "Rose did not entertain the possibility that Woolf is describing two different episodes” (DeSalvo, 1989: p. 4).

Perhaps the worst example of "victim-blaming” given by DeSalvo (1998) comes from Lyndall Gordon's Virginia Woolf: A writer's life, published in 1984: "it is impossible to know what truly happened"; "George's behavior... may have been irresistible to a girl like Virginia"; ... he was "thought very handsome and his combination of sensual lips and considerate manners made him the pet of society ladies” (DeSalvo, 1989: p. 5). Unfortunately, this attitude of disbelief still permeates CSA survivors until today, and the low rates of judiciary convictions of sexual offenses as shown by Whitcomb \& De Vos (1995), confirm this bias.

\subsection{Woolf's Coping Skills}

With her gifted intellectual skills, Woolf made several attempts to heal herself from her traumatic experiences. She disclosed to friends and supportive relatives; she engaged in frequent narrative acts and diary writing. Reading one's memories aloud in public is as close as one could get, in the early $20^{\text {th }}$ century, to today's CAS disclosure and reporting procedure. Woolf's writing helped her alleviate her suffering, and she interprets that "the shock-receiving capacity is what makes me a writer" (Woolf, 1985b: p. 72).

She strives to find meaning in her traumatic experiences, as presently recommended by clinicians and trauma experts (Cohen, Mannarino, \& Deblinger, 2006). In A sketch of the past, Woolf acknowledges some of the pro- 
tective factors which accompanied her: "born not of rich parents, but of well-to-do parents, born into a very communicative, literate, letter writing, visiting, articulate, late nineteenth century world” (Woolf, 1985b: p. 65).

Woolf also behaves as a scientist. DeSalvo (1989) quotes her diary entry: "I am interested in depression” (p. 99), as she tries to understand this phenomenon, her introspective writing attempts to describe historical facts, feelings and patterns associated with her depression. Writing a personal diary and keeping track of the frequency of negative events with its depressive consequences may be seen as today's systematic record-keeping and clinical self-analysis. Presently, an expert practitioner would have also encouraged her to keep records of positive emotions and events.

Virginia Woolf also looks for professional help by reading the most renowned clinician of her time-Sigmund Freud. According to DeSalvo (1989), Woolf starts writing her autobiography "A Sketch of the past”, perhaps influenced by Freud after reading his work (Virginia and Leonard's Hogarth Press began to publish Freud's work in English, in 1921, according to Schowalter, 1992). DeSalvo mentions that a few months before she began writing her memoirs, Woolf went to see Freud and began a project she "came to describe as autoanalysis" (DeSalvo, 1989: p. 99), and quotes from Woolf's diary in which she "tries to center by reading Freud" (p. 127).

DeSalvo (1998) mentions that reading Freud helped Woolf understand her own mother in more realistic terms: "she began to think of the ambivalence toward her parents" (p. 118). The actual quote from Woolf's autobiography when analyzing her feelings towards her father is: "It was only the other day when I read Freud for the first time, that I discovered that this violently disturbing conflict of love and hate is a common feeling; and it is called ambivalence” (Woolf, 1985b: p. 108). Jeanne Schulkind's footprint indicates the precise date to be December 2, 1939, and according to her diary entry: "Began reading Freud last night; to enlarge the circumference, to give my brain wider scope, to make it objective; to get outside. Thus defeat the shrinkage of age” (Woolf, 1992: p. 108).

At some point, DeSalvo speculates that there must have been significant discrepancy between Woolf's own explanation of depression as attributed to CSA, and Freud's reports of "incest as fantasies which were wish-fulfillment", leading Woolf to conclude that, if Freud was right, then she was "mad". As evidence, DeSalvo quotes Woolf's entry from December 9, 1939: "Freud is upsetting: reducing one to whirlpool; \& I daresay truly. If we are all instinct, the unconscious, what's all this about civilization, the whole man, freedom” (DeSalvo, 1989: p. 127).

Schowalter (1992) argues that Woolf was overtly dismissive of psychoanalysis, developing her own psychological method of explaining sensation, memory and repression, and that like Freud, Woolf believed that much in adult identity was formed in early childhood. Unfortunately, the present author could not locate the original information mentioned by DeSalvo (1989) or others relating to the conversation Woolf had with Freud when she went to see him on January 29, 1939, other than irrelevant remarks that he gave her a narcissus (DeSalvo, 1989); and that she found him old, ill, and considered his English less than perfect (Marder, 2000). Lee (1999) also informs that Woolf talked to Freud about Hitler, and admits that she was "thrown into violent confusion by reading Freud" (p. 710).

DeSalvo (1989) mentions the fact that Freud abandoned his "seduction theory" earlier in his career, where he had claimed that (quoting Alice Miller): "at the bottom of every case of hysteria there are one or more occurrences of premature sexual experiences” (DeSalvo, 1998, p. 7). She also quotes Judith Lewis Herman, saying that "Freud was never comfortable with his discovery about the prevalence of sexual abuse and its effect because of what it implied about the behavior of respectable family men” (DeSalvo, 1989: p. 7).

DeSalvo cites briefly Jeffrey Moussaief Masson's The Assault on Truth: Freud's suppression of the Seduction Theory. Indeed, Masson (1984) had access to invaluable material, in his capacity as Director of the Freud Archives. In his fascinating book, he explains that Freud went, as a young medicine student, to Paris in 1985, where he was introduced to the pioneer work of Ambroise Tardieu describing CSA from a medical perspective. Freud, then, under Tardieu's influence writes about CSA from a psychological perspective. According to Masson, although Freud makes an unfortunate choice of words for his "seduction theory", developed in 1896, he was truly interested in the psychological impact of early sexual trauma. Strong criticism from psychoanalytic colleagues in Vienna made Freud abandon this theory, in 1905, claiming early sexual experiences as fantasies, such as the Oedipus complex. (For information on Ambroise Tardieu-outstanding French forensic physician who first noticed child abuse as a medical and public health problem one century before North-Americans-see Labbé, 2005).

Regardless of the speculation by DeSalvo that Freud's pessimistic view of human nature is partially to be 
blamed for Woolf's suicide, the fact is that Woolf did not receive support from the physicians who saw her. Schowalter (1992), describes her "unhappy experience with doctors" in which she was treated for a "rest cure"-a therapy designed for nervous women by the American physician Silas Weir Mitchell, imported to England in 1880s, involving "isolation, complete bed rest for up to six weeks, a rich diet and enforced weight gain, and the absence of all intellectual activity" (Schowalter, 1992: p. xli).

\subsection{Woolf's Multiple Forms of Victimization}

Although the severity of the CSA experienced by Woolf is possibly the strongest stressor she suffered, perhaps she is better described in today's term as having been poly-victimized in her childhood-that is, she had different episodes of victimization over the course of the same year (Finkelhor, 2008). Even though DeSalvo justifies the parenting Woolf received as a consequence of historical and political variables (e.g. patriarchalism), there is room in Leslie and Julia's parenting for much contention of individual variables which could be considered risky for healthy development, well beyond the Victorian cultural context.

Woolf's idealized view of her parents, as in the excerpt from her diary quoted by DeSalvo (1989), is often observed amongst adults who are psychologically abused as children:

"How beautiful they were those old people-I mean father \& mother-how simple, how clear, how untroubled, I have been dipping into old letters \& fathers memoirs. He loved her-oh \& was so candid \& reasonable \& transparent... How serene \& gay even their life reads to me: no mud; no whirlpools. And so human - with the children \& the little hum \& song of the nursery” (p. 131).

Woolf's parents' life was far from serene. Her father had several depressive episodes before losing his second wife (Figueiroa, 2005); Woolf quotes her mother after losing Herbert Duckworh (therefore before she was born), as being "as unhappy as it is possible for a human being to be.” (Woolf, 1985b: p. 89); DeSalvo quotes Woolf writing that her mother's photograph "depicts a seriously depressed woman'(p. 114); and DeSalvo speculates that Julia's depression was a response to her own lack of parenting, although the reverse is true-a depressive mother often has parenting difficulties, which in turn negatively affect children's development (Goodman \& Gotlib, 1999).

Both parents used severe punishment with Laura, Leslie's older daughter, who also may have, according to DeSalvo, 1989, been sexually victimized by Gerald and George. Such punishment involved isolation, confinement, and increasingly stronger doses of medication, although one may argue, as Lee (1999) does that these were traditional Victorian practices. DeSalvo mentions that in writing "A Sketch of the Past", in addition to positive aspects, Woolf describes negative characteristics of both her father (rather violent, prone to rage episodes and despotism), and mother (unavailability to her children: "Can I remember ever being alone with her for more than a few minutes? Someone was always interrupting” (Woolf, 1985b: p. 83). The consequence, Woolf says of her mother's "self-surrender" to Leslie Stephen's need, was that "life seemed to us in a chronic state of confusion. We were quite naturally unhappy" (p. 45).

Woolf's reports on her mother's relationship with her half-sister Stella is also revealing: Stella was a child who "lived in the shade of widowhood" (Woolf, 1985b: p. 96), referring to Julia's hardship in recovering from Herbert Duckworth's death, and her sister developed an "attitude of devotion, almost canine in its touching adoration, to her mother, that passive, suffering affection; and also that complete unquestioning dependence" (Woolf, 1985b: p. 96). Woolf describes her mother as being "stern" and "harsh" with Stella who "was treated severely" by Julia Stephen-a mother whose "devotion” was given to George and Gerald (96). Not surprisingly, Stella "thought of herself so stupid” (p. 97).

Lee (1999) describes Woolf's mother as "reticent and aloof" and "very sad" (p. 81), someone who had been "passionately in love with the first husband and who used to lie on his grave, according to daughter Stella. We may speculate that non-responsiveness criticized by Woolf may have been signs of depression, although Lee correctly points out that Julia Stephens neglected her own children as she "spread herself thinly between... husband first, eight children...” (p. 81), and was exhausted as she lived at a time that she had to nurse the sick and the dying.

Bell's description (Bell, 1972) of Woolf's father's oppressive and despairing behaviors, particularly after losing his second wife suggests touches of histrionism. Woolf hints that her father may have been sexually abusive to Stella (who herself had been previously raped by a cousin). DeSalvo informs that Woolf's half-sister had to 
"accommodate the needs of her stepfather" (p. 58); postpone her marriage; and that "Woolf clearly interpreted Stella's and Leslie's behavior as incestuous” (DeSalvo, 1989: p. 57). In A sketch of the past, Woolf writes that her father became increasing "tyrannical” after Stella became engaged, and that he was “jealous clearly” (Woolf, 1985b: p. 106).

Woolf narrates in the same autobiography the absence of her mother and father after their deaths, not on nostalgic terms, but as an "obsession". This "invisible presence" (Woolf, 1985b: p. 80) only disappeared when, inspired by her parents she wrote the novel To the Lighthouse, in which she is critical of Victorian parenting. Woolf mentions that during the seven years between Stella's death and her father's, she was "fully exposed without protection to the full blast of that strange character" (Woolf, 1985b: p. 107). This character is described in different parts of the autobiography as being "strangely brisk", and "embittered" (p. 55):

"the tyrant father-the exacting, the violent, the histrionic, the demonstrative, the self-centered, the self pitying, the deaf, the alternative appealing, the alternately loved and hated father-that dominated me. It was like being shut up in the same cage with a wild beast” (Woolf, 1985b: p. 116).

She tries to link the motivation for Leslie Stephen's “violent temper” (Woolf, 1985b: p. 109) to the fact that he was spoilt as a child, and his frustrations as he desired to be "a man of genius", and considered himself "only a good second class mind" (p. 110), or that he was "conscious of his failure as a philosopher" (p. 145). She discriminates that her father indulged his rage particularly towards women-"Partly of course because woman was then... the slave” (p. 145), and partly because he was emotionally dependent on women.

The CSA experienced in the household after Woolf's mother's death was public-her father knew of it, and appears to have been negligent about this serious occurrence. DeSalvo (1989) quotes Woolf's nephew, Quentin Bell, in his biography: “... after the death of Julia Stephen... Woolf's mother: there were fondlings and fumblings in public... and these were carried to greater lengths...” (DeSalvo, 1989: p. 2). The fact that no one came to help the girls who were being abused may also be exemplified in Woolf's statement that "a finger was laid on our lips" (DeSalvo, 1989: p. 120), during the "Greek slave” years, as Woolf termed the phase in which George abused her sister Vanessa and herself after their mother's death.

If we accept the possibility that Woolf had other forms of maltreatment (such as negligence or psychological abuse) besides CSA, the risk of severe psychopathology in adulthood is maximized. It is sufficient to mention that, in addition to the possibility of being exposed to abusive parenting, Woolf suffered other adverse episodes in her adolescence in the form of family losses (her mother died at the very beginning of Woolf's adolescence, and her sister Stella, who had an affectionate and protective role, died a few years later-both deaths had shattering effects on the family). The point argued here is that certain family variables (such as lack of parental warmth) may be confounded with CSA and explain some of the difficulties observed, as also defended by the literature (Maniglio, 2009; Rind, Tromovich, \& Bauserman, 1998).

\subsection{Woolf's Contribution to CSA Knowledge}

DeSalvo (1989) defends—and justly so—-that Virginia Woolf was a pioneer in exploring the effects of CSA, well before other incest survivors, "anticipating, by thirty years or so, inquiry into the relationship between childhood abuse and the formation of personality” (p. 124). In addition, DeSalvo contends that Woolf was also a visionary in describing the structure of the patriarchal family, and by examining "the betrayal of the child's right to protection within the family" (DeSalvo, 1989: p. 305).

And she did all this with exceptional mastery of the English language, offering superb metaphorical imagery that is of great benefit to clinicians and the general public to understand the experience of a CSA survivor, as when Woolf describes feeling around George like "an unfortunate minnow shut up in the same tank with an unwieldy and turbulent whale", and that visiting Gerald was like "visiting an alligator in a tank, an obese \& obsolete alligator"1 (DeSalvo, 1989: p. 111 and 109 respectively), or still when she describes the feelings associated with the first episode of CSA, by Gerald Duckworth:

"I remember resenting, disliking it-what is the word for so dumb and mixed feeling? It must have been strong, since I still recall it. This seems to show that a feeling about certain parts of the body; how they must not be touched; how it is wrong to allow them to be touched; must be instinctive” (Woolf, 1985: p.

${ }^{1}$ In one of Woolf's few references to Gerald in her adult life, we learn here that she had not seen him for 20 years. 
69).

She also described with precision in 22 Hyde Park Gate the confusion of roles faced by children of incestuous families: "Yes, the old ladies... never knew that George Duckworth was not only father and mother, brother and sister to those poor Stephen girls. He was their lover also" (Wolf, 1985c: p. 177).

Woolf's intuition about psychology is phenomenal. Many of her sayings are found much later in different psychological schools of thoughts. Evolutionary psychologists would agree with her statement in A sketch of the past, following her descriptions of feelings associated with the first abuse episode, about the possibility of sexual behavior being instinctive: "It proves that Virginia Stephen was not born on the 25th January 1882, but was born many thousands of years ago; and had from the very first to encounter instincts already acquired by thousands of ancestresses in the past” (Woolf, 1985b: p. 69).

When she describes her first memories, she anticipates Daniel Gilbert and other social psychologist's research (Gilbert, 2006) by at least half a century by saying that "Unfortunately, one only remembers what is exceptional" (Woolf, 1985b: p. 69). In addition, DeSalvo (1989) quotes Woolf in "A sketch from the past" defending that "a great part of everyday is not lived consciously" (p. 103); in which she agrees with two of the most influential men in $20^{\text {th }}$ century psychology - Freud and Skinner. The latter also claimed that, to a large extent, people are controlled by forces of which they are not conscious (Overskeid, 2007). Woolf even uses the term psychologist as a qualifier in a positive light. When describing her abusive brother in Moments of being, she writes: "But poor George was no psychologist. His perceptions were obtuse. He never saw within” (Woolf, 1985b: p. 171).

In addition to her revolutionary, unique and modernist prose, as a feminist she contributed much to subsequent gender discussions, adding to her enormous legacy. And the fact that she was never allowed to go to school, as her brothers did, reflects many of the injustices women faced-and still do in some parts of the world-and is only more evidence of her genius.

\section{Conclusion}

In his 1998 Pulitzer Prize winning book The Hours (later filmed with Nicole Kidman in Woolf's role), the writer Michael Cunningham inserts a beautifully written extract from Virginia Woolf's Mrs. Dalloway (Cunningham, 1998), in which the character Laura Brown (portrayed in the film by the actress Julianne Moore), asks herself how could someone who was able to write a sentence with such intense positive emotion commit suicide?.

Playwright Edward Albee gave Woolf the title of one of his renowned plays: Who's afraid of Virginia Woolf? Playing off of Albee's title, the present paper addresses the question raised by Michal Cunningham: we may ask What was Virginia Woolf afraid of? The answer is conclusive to the traumatic history of her sexual victimization whose complex dynamics is often still misunderstood not only by lay biographers but by the public in general.

\section{Acknowledgements}

I would like to thank Julia Calder with help proof-reading this paper, and Ph.D. student Paolla Santini for helping with CSA revision.

\section{References}

Bell, Q. (1972). Virginia's Woolf: A Biography. San Diego: Harcourt Brace Jovanovich Publishers.

Briere, J. (1992). Child Abuse Trauma: Theory and Treatment of the Lasting Effects. Newbury Park: Sage.

Browne, A., \& Finkelhor, D. (1986). Impact of Child Sexual Abuse: A Review of the Research. Psychological Bulletin, 99, 66-77. http://dx.doi.org/10.1037/0033-2909.99.1.66

Cashmore, J., \& Shackel, R. (2013). The Long-Term Effects of Child Sexual Abuse. Child Family Community Australia, 11, 1-29. http://www.aifs.gov.au/cfca/pubs/papers/a143161/cfca11.pdf

Chelf, M., \& Ellis, J. B. (2002). Young Adults Who Were Sexually Abused Demographics as Predictors of Their Coping Behaviors. Child Abuse \& Neglect, 26, 313-316. http://dx.doi.org/10.1016/S0145-2134(01)00327-1

Cohen, J. A., Mannarino, A. P., \& Deblinger, E. (2006). Treating Trauma and Traumatic Grief in Children and Adolescents. New York: Guilford Press.

Cohen, M. A. (1995). French Toast for Breakfast: Declaring Peace with Emotional Eating. Carlsbad: Gürze Books.

Cunningham, M. (1998). The Hours. New York: Farrar, Straus and Giroux. 
Cutajar, M. C., Mullen, P. E., Ogloff, J. R. P., Thomas, S. D., Wells, D. L., \& Spataro, J. (2010). Psychopathology in a Large Cohort of Sexually Abused Children Followed up to 43 Years. Child Abuse \& Neglect, 34, 813-822. http://dx.doi.org/10.1016/j.chiabu.2010.04.004

Deblinger, E., \& Heflin, A. H. (1996). Treating Sexually Abused Children and Their Non-Offending Parents: A Cognitive Behavioral Approach. Thousand Oaks, CA: Sage Publications.

DeSalvo, L. (1989). Virginia Woolf: The Impact of Childhood Sexual Abuse on Her Life and Work. New York: Ballantine Books.

DeSalvo, L. (1999). Writing as a Way of Healing: How Telling Stories Transforms our Lives. Boston, MA: Beacon Press.

Dworkin, E., Javdani, S., Verona, E., \& Campbell, R. (2014). Child Sexual Abuse and Disordered Eating: The Mediating Role of Impulsive and Compulsive Tendencies. Psychology of Violence, 4, 21-36. http://dx.doi.org/10.1037/a0031779

Evans, E., Hawton, K., \& Rodham, K. (2005). Suicidal Phenomena and Abuse in Adolescents: A Review of Epidemiological Studies. Child Abuse \& Neglect, 29, 45-58. http://dx.doi.org/10.1016/j.chiabu.2004.06.014

Fergusson, D. M., McLeod, F. H. G., \& Horwood, L. J. (2013). Childhood Sexual Abuse and Adult Developmental Outcomes: Findings from a 30-Year Longitudinal Study in New Zealand. Child Abuse \& Neglect, 37, 664-674. http://dx.doi.org/10.1016/j.chiabu.2013.03.013

Figueiroa, G. C. (2005). Virginia Woolf: Enfermedad mental y creatividad artistic [Virginia Woolf: Mental Illness and Artistic Creation]. Revista Médica de Chile, 133, 1381-1388.

Finkelhor, D. (1990). Early and Long-Term Effects of Child Sexual Abuse: An Update. Professional Psychology: Research \& Practice, 21, 325-330. http://dx.doi.org/10.1037/0735-7028.21.5.325

Finkelhor, D. (2008). Children at Risk. In D. Finkelhor (Ed.), Childhood Victimization: Violence, Crime and Abuse in the Lives of Young People (pp. 47-64). New York: University Press. http://dx.doi.org/10.1093/acprof:oso/9780195342857.003.0003

Foa, E. B., Molnar, C., \& Cashman, L. (1995). Change in Rape Narratives during Exposure Therapy for PTSD. Journal of Traumatic Stress, 8, 675-690. http://dx.doi.org/10.1002/jts.2490080409

Follette, V. M. (1994) Survivors of Child Sexual Abuse: Treatment Using a Contextual Analysis. In S. Hayes, N. Jacobson, V. Follette, \& M. Dougher (Eds.), Acceptance and Change: Content and Context in Psychotherapy (pp. 255-268). Reno, NV: Context Press.

Follette, V. M., Polusny, M. A., Bechtle, A. E., \& Naugle, A. E. (1996). Cumulative Trauma: The Impact of Child Sexual Abuse, Adult Sexual Assault, and Spouse Abuse. Journal of Traumatic Stress, 9, 25-35. http://dx.doi.org/10.1002/jts.2490090104

Follette, V., Ruzek, J., \& Abueg, F. (1998) Cognitive-Behavioral Therapies for Trauma. New York: The Guilford Press.

Gilbert, D. (2006). Stumbling on Happiness. New York: Random House.

Goodman, S. H., \& Gotlib, I. H. (1999). Risk for Psychopathology in the Children of Depressed Mothers: A Developmental Model for Understanding Mechanisms of Transmission. Psychological Review, 106, 458-490. http://dx.doi.org/10.1037/0033-295X.106.3.458

Hilberg, T., Hamilton-Giachritsis, C., \& Dixon, L. (2011). Review of Meta-Analysis on the Association between Child Sexual Abuse and Adult Mental Health Difficulties: A Systematic Approach. Trauma, Violence, \& Abuse, 12, 38-49. http://dx.doi.org/10.1177/1524838010386812

Kaplow, J. B., Hall, E., Koenen, K. C., Dodge, K. A., \& Amaya-Jackson, L. (2008). Dissocitation Predicts Later Attention Problems in Sexually Abused Children. Child Abuse \& Neglect, 32, 261-275. http://dx.doi.org/10.1016/j.chiabu.2007.07.005

Kendall-Tackett, K. A.,Williams, L. M., \& Finkelhor, D. (1993). Impact of Sexual Abuse on Children: A Review and Synthesis of Empirical Findings. Psychological Bulletin, 113, 164-180. http://dx.doi.org/10.1037/0033-2909.113.1.164

Kendler, K. S., Bulik, C. M., Silberg, J., Hettema, J. M., Myers, J., \& Prescott, C. A. (2000). Childhood Sexual Abuse and adult Psychiatric and Substance Use Disorders in Women: An Epidemiological and Cotwin Control Analysis. Archives of General Psychiatry, 57, 953-959. http://dx.doi.org/10.1001/archpsyc.57.10.953

Kermode, F. (2000). Biographical Preface. In V. Woolf (Ed.), To the Lighthouse (pp. 7-11). Oxford: Oxford University Press.

Koenig, L. J., Doll, L. S., O’Leary, A., \& Pequegnat, W. (2004). From Child Abuse to Adult Sexual Risk: Trauma, Revictimization, and Intervention. Washington DC: American Psychological Association.

Labbé, J. (2005). Ambroise Tardieu: The Man and His Work on Child Maltreatment a Century before Kempe. Child Abuse \& Neglect, 29, 311-324. http://dx.doi.org/10.1016/j.chiabu.2005.03.002

Lacelle, C., Hébert, M., Lavoie, F., Vitaro, F., \& Tremblay, R. E. (2012). Sexual Health in Women Reporting a History of 
Child Sexual Abuse. Child Abuse \& Neglect, 36, 247-259. http://dx.doi.org/10.1016/j.chiabu.2011.10.011

Lee, H. (1999). Virginia Woolf. New York: Vintage Books.

Leitenberg, H., Greenwald, E., \& Cado, S. (1992). A Retrospective Study of Long Term Methods of Coping with Having Been Sexually Abused during Childhood. Child Abuse \& Neglect, 16, 399-407. http://dx.doi.org/10.1016/0145-2134(92)90049-W

Lemieux, S. R., \& Byers, S. E. (2008). The Sexual Well-Being of Women Who Have Experienced Child Sexual Abuse. Psychology of Women Quarterly, 32, 126-144. http://dx.doi.org/10.1111/j.1471-6402.2008.00418.x

Liu, R. T. (2010). Early Life Stressors and Genetic Influences on the Development of Bipolar Disorder: The Roles of Childhood Abuse and Brain-Derived Neutrophic Factor. Child Abuse \& Neglect, 34, 516-522.

http://dx.doi.org/10.1016/j.chiabu.2009.10.009

Maniglio, R. (2009). The Impact of Child Sexual Abuse on Health: A Systematic Review of Reviews. Clinical Psychology Review, 29, 647-657. http://dx.doi.org/10.1016/j.cpr.2009.08.003

Maniglio, R. (2011). The Role of Child Sexual Abuse in the Etiology of Suicide and Non-Suicide Self-Injury. Acta Psychiatrica Scandinavica, 124, 30-41. http://dx.doi.org/10.1111/j.1600-0447.2010.01612.x

Maniglio, R. (2013). The Impact of Child Sexual Abuse on the Course of Bipolar Disorder: A Systematic Review. Bipolar Disorders, 15, 341-358.

Marder, H. (2000). The Measure of Life: Virginia Woolf's Last Years. Ithaca: Cornell University Press.

Martin, G., Bergen, H. A., Richardson, A. S., Roeger, L., \& Allison, S. (2004). Sexual Abuse and Suicidality: Gender Differences in a Large Community Sample of Adolescents. Child Abuse \& Neglect, 28, 491-503. http://dx.doi.org/10.1016/j.chiabu.2003.08.006

Masson, J. M. (1984). The Assault on Truth: Freud's Suppression of the Seduction Theory. New York: Farrar, Straus \& Giroux.

Meichenbaum, D. (1994). Victims of Child Sexual Abuse. In D. Meichenbaum (Ed.), A Clinical Handbook/Practical Therapist Manual for Assessing and Treating Adults with Post-Traumatic Stress Disorder (PTSD) (pp. 81-91). Waterloo: Institute Press.

O’Donohue, W., Fanetti, M., \& Elliot, A. (1998). Trauma in Children. In V. Follette, J. Ruzek, \& F. Abueg (Eds.), Cognitive-Behavioral Therapies for Trauma (pp. 355-382). New York: The Guilford Press.

Overskeid, G. (2007). Looking for Skinner and Finding Freud. American Psychologist, 62, 590-595. http://dx.doi.org/10.1037/0003-066X.62.6.590

Padovani, R., \& Williams, L. (2010). Family Violence History and Poverty among Psychiatric Patients in Brazil. In G. Lovisi, J. Mari, \& E. Valencia (Eds.), The Psychological Impact of Living under Violence and Poverty in Brazil (pp. 91-103). New York: Nova Science Publishers.

Rind, B., Tromovich, P., \& Bauserman, R. (1998). A Meta-Analytic Examination of Assumed Properties of Child Sexual Abuse Using College Samples. Psychological Bulletin, 124, 22-53. http://dx.doi.org/10.1037/0033-2909.124.1.22

Sanci, L., Coffey, C., Olsson, C., Reid, S., Carlin, J. B., \& Patton, G. (2008). Childhood Sexual Abuse and Eating Disorders in Females: Findings from the Victorian Adolescent Health Cohort Study. Archives of Pediatrics \& Adolescent Medicine, 162, 261-267. http://dx.doi.org/10.1001/archpediatrics.2007.58

Schowalter, E. (1992) Introduction. In V. Woolf (Ed.), Mrs. Dalloway (pp. 11-14). London: Penguin Books.

Schulkind, J. (1985). The Memoir Club Contributions: Editor's Note. In V. Woolf (Ed.), Moments of Being: A Collection of Autobiographical Writing (pp. 161-163). Orlando, FL: Harcourt, Inc.

Shenk, C. E., Noll, J. G., Putnam, F. W., \& Trickett, P. K. (2010). A Prospective Examination of the Role of Childhood Sexual Abuse and Physiogogical Asymmetry in Development of Psychopathology. Child Abuse \& Neglect, 34, 753-761.

Simon, V. A., \& Feiring, C. (2008). Sexual Anxiety and Eroticism Predict the Development of Sexual Problems in Youth with a History of Sexual Abuse. Child Maltreatment, 13, 167-181. http://dx.doi.org/10.1177/1077559508315602

Smolak, L., \& Murren, S. K. (2002). A Meta-Analytic Examination of the Relationship between Child Sexual Abuse and Eating Disorders. International Journal of Eating Disorders, 31, 136-150. http://dx.doi.org/10.1002/eat.10008

Stephenson, K. R., Hughan, C. P., \& Meston, C. M. (2012). Childhood Sexual Abuse Moderates the Association between Sexual Functioning and Sexual Distress in Women. Child Abuse \& Neglect, 36, 180-189. http://dx.doi.org/10.1016/j.chiabu.2011.09.015

Thompson, K. M., \& Wonderlich, S. A. (2004). Child Sexual Abuse and Eating Disorders. In: K. M. Thompson, \& S. A. Wonderlich (Eds.), Handbook of Eating Disorders and Obesity (pp. 679-694). Hoboken, NJ: John Wiley \& Sons.

Wagner, A. W., \& Linehan, M. M. (1998). Dissociative Behavior. In: V. Follette, J. Ruzek, \& F. Abueg (Eds.), Cognitive- 
Behavioral Therapies for Trauma (pp. 191-225). New York: The Guilford Press.

Whitcomb, D., \& De Vos, E. (1995). Criminal Justice Outcomes of Prosecution of Child Sexual Abuse: A Case Flow Analysis. Child Abuse \& Neglect, 19, 1431-1442. http://dx.doi.org/10.1016/0145-2134(95)00106-2

Woolf, V. (1985a). Am I a Snob? In V. Woolf (Ed.), Moments of Being: A Collection of Autobiographical Writing (pp. 204-220). Orlando, FL: Harcourt, Inc.

Woolf, V. (1985b). A Sketch from the Past. In V. Woolf (Ed.), Moments of Being: A Collection of Autobiographical Writing (pp. 61-159). Orlando, FL: Harcourt, Inc.

Woolf, V. (1985c). 22 Hyde Park Gate. In V. Woolf (Ed.), Moments of Being: A Collection of Autobiographical Writing. (pp. 164-177). Orlando, FL: Harcourt, Inc.

Woolf, V. (1992). Mrs. Dalloway. London: Penguin Books. 
Scientific Research Publishing (SCIRP) is one of the largest Open Access journal publishers. It is currently publishing more than 200 open access, online, peer-reviewed journals covering a wide range of academic disciplines. SCIRP serves the worldwide academic communities and contributes to the progress and application of science with its publication.

Other selected journals from SCIRP are listed as below. Submit your manuscript to us via either submit@scirp.org or Online Submission Portal.
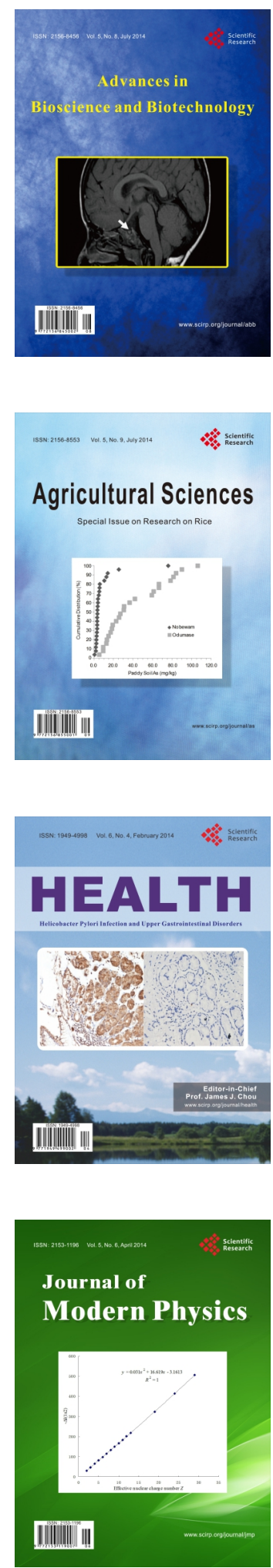
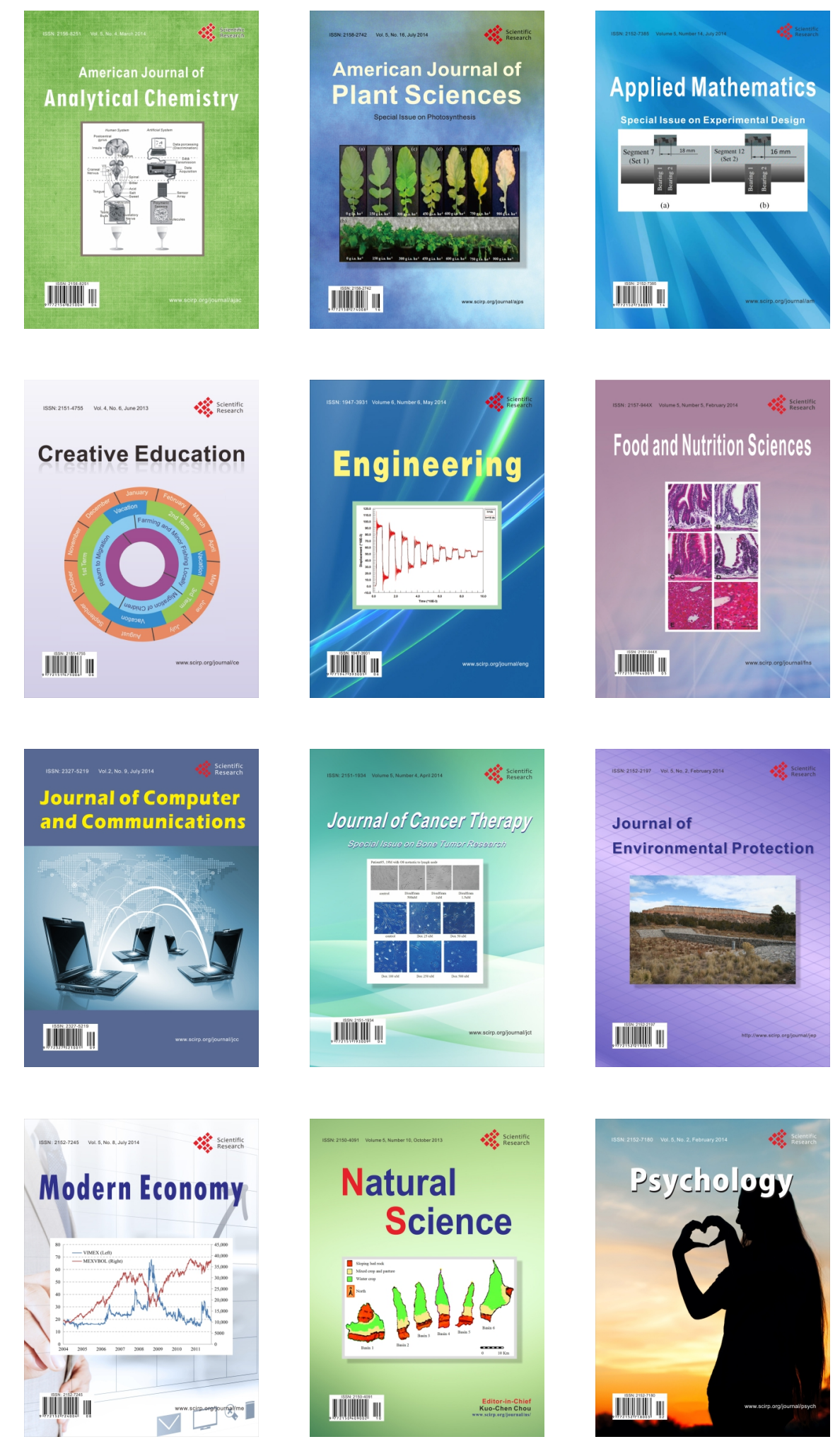